\title{
Słowo wstęne
}

$\mathrm{R}$ ocznice nierzadko są dobrą okazją do podjęcia określonych tematów badań historycznych. Tak też stało się z projektem przedkładanym właśnie szanownym Czytelnikom. Osiemdziesiąt lat temu, 17 lipca 1936 r. wybuchła wojna domowa w Hiszpanii. Rebelia wojskowych zaczęła się wprawdzie poza metropolią, ale w kolejnych dniach ukazała swą siłę także na Półwyspie Pirenejskim. Na temat konfliktu, który niewątpliwie groził antagonizmem na skalę szerszą niż tylko wewnątrzhiszpańska, napisano już setki książek i artykułów, tak naukowych, jak i publicystycznych. Niemało tytułów można by wskazać także w polskiej literaturze naukowej, choć jest to oczywiście promil w porównaniu z pracami stworzonymi w języku hiszpańskim, angielskim czy innym.

Tematyka wojny domowej w Hiszpanii, mimo upływu lat, nie traci na popularności. Związane jest to z wieloma czynnikami, w tym z emocjami, które nadal nieodłącznie towarzyszą temu problemowi. Emocje z kolei biorą się głównie z rozmiaru strat, zadanych sobie nawzajem przez obie strony konfliktu. Ofiary ludzkie i materialne cały czas stanowią żywe wspomnienie potomków osób, które utraciły swoich najbliższych. Ale nie bez znaczenia jest uwarunkowanie ideologiczne zmagań, w które zaangażowali się ludzie spoza Hiszpanii. Wojna domowa była niejednokrotnie przedstawiana propagandowo jako „,walka z faszyzmem”, przeprowadzana w imię „obrony demokracji i wolności”. Tak starali się sprawę prezentować zwolennicy utworzonego po wyborach z 16 lutego 1936 r. rządu Frontu Ludowego. Dodawali, że bronią ,ludu hiszpańskiego” przed „obcymi najeźdźcami”, chcącymi narzucić im porządki faszystowskie. Z kolei druga strona mobilizowała swoich zwolenników do walki przeciwko ,inwazji czerwonej zarazy", zamierzającej narzucić mającemu długowiekowe tradycje, dumnemu narodowi „obcy porządek”, przywożony przez „Sowietów”. W Hiszpanii komunizm kojarzył się z bałaganem, bezprawiem, bezbożnością, chaosem gospodarczym i terrorem. Rządy, które zapanowały po lutowych wyborach 1936 r., przedstawiane były jako przedsmak tego, co mogłoby się wydarzyć w kraju, gdyby trwały one dłużej. Nietrudno jest zauważyć, że prezentowanie przeciwników w taki sposób miało na celu wzbudzenie wobec nich negatywnych emocji, zarówno w kraju, jak i poza granicami objętego wojną domową państwa.

Z emocjami wiążą się podstawowe utrudnienia w podejmowaniu tematu wojny w Hiszpanii. W przedkładanym tomie widać to choćby po stosowanym słownictwie, którym próbowano nazywać strony konfliktu w dyskursie naukowym. Nie 
pojawia się tutaj co prawda dychotomia „faszyści kontra komuniści”, tak chętnie używana w historiografii okresu PRL. Ale już nazwanie stronników generała Francisco Franco „obozem narodowym”, „nacjonalistami”, „rebeliantami”, „puczystami” czy „obalającymi demokratyczny ustrój siłą”, a może po prostu „powstańcami” wskazywać może na sympatie piszącego. Tak samo jest zresztą z nazewnictwem dotyczącym ich przeciwników. Czy powinno się ich określać jako „republikanów” czy jako „lojalistów”, czy jako „zwolenników demokratycznie wybranego rządu”, czy „przeciwników faszyzmu”, a może po prostu ,protegowanych Moskwy"? Wszystkie wskazane propozycje (nie wyczerpano tutaj zresztą wachlarza możliwości) niosą za sobą swoisty ładunek emocjonalny: bądź negatywny, bądź też pozytywny. Oddają one w jakimś zakresie specyfikę tego, co chce się o walczących obozach powiedzieć, i jednocześnie zaciemniają precyzję, wprowadzając element oceny. Biorąc dodatkowo pod uwagę potrzeby językowe, na użytek poprawnej konstrukcji zdań potrzebne są w miarę krótkie, precyzyjne określenia, pozwalające na ich użycie jako podmiotu w konstruowanych frazach. Trzeba jednakże zauważyć niebezpieczeństwo używania takiej terminologii z powodu uproszczeń znaczeniowych.

Na pewno, poza samym nazewnictwem, problemem staje się krytyka przytaczanych źródeł, w równie wysokim stopniu nasyconych emocjonalnie. Na obecnym poziomie badań dotyczących wojny domowej w Hiszpanii naukowcy nie spierają się o fakty, gdyż te zostały już w znakomitej większości drobiazgowo ustalone. Natomiast ich interpretacja cały czas pozostaje kwestią sporną. Jest tak zarówno w przypadku źródeł, jak i pozostającej do dyspozycji badaczy literatury naukowej. Niemalże wszyscy uczestnicy tego tomu narzekali na trudności interpretacyjne w przygotowywanym przez siebie tekście.

Jak zauważono, obie walczące w Hiszpanii strony powoływały się w swojej retoryce na walkę przeciwko „obcym”. Właśnie „obcym” dla narodu hiszpańskiego nazywano z jednej strony faszyzm, a z drugiej komunizm i rewolucję. „Obcy” to także mocarstwa europejskie, które angażowały się w wewnętrzne sprawy Hiszpanii. Krytykowano więc z jednej strony Włochy, Niemcy i Portugalię, a z drugiej Związek Sowiecki z powodu interwencji tych rządów w hiszpańskiej wojnie domowej. Ale krytyka objęła również władze Wielkiej Brytanii i Francji, ponieważ oficjalnie nie angażowały się w zmagania na Półwyspie Pirenejskim i to właśnie polityka nieinterwencji sprzyjać miała generałom występującym przeciwko legalnie wybranemu rządowi w Madrycie. W przedkładanym tomie wielka polityka międzynarodowa nie będzie jednakże głównym bohaterem. Jak wskazuje na to tytuł, to cudzoziemcy walczący po obu stronach konfliktu wyeksponowani zostali na pierwszy plan. Rzecz jasna, część z nich znalazła się na hiszpańskich frontach z powodu polityki własnego rządu, ale celem opracowania będzie odpowiedź na pytanie, w jakim stopniu tak się stało, a w jakim była to indywidualna inicjatywa przybyszów zza granicy. Oprócz zbadania motywów osób walczących w Hiszpanii (niełatwych do sprecyzowania), ważne będzie ustalenie choćby przybliżonej 
liczebności obcokrajowców, charakteru i struktury tworzonych przez nich oddziałów, sposobu rekrutacji i przerzucania ludzi na miejsce walk, a także ich traktowania na polach bitewnych. Bardzo istotna do poruszenia wydaje się kwestia ustalenia strat walczących w Hiszpanii obcokrajowców. Ta jednakże rodzi trudności, ponieważ ani obie walczące strony nie prowadziły takich statystyk, ani też kraje, z których pochodzili kombatanci, nie zamierzały ich ujawniać. W tomie istotne będzie pokazanie zaangażowania się cudzoziemców w konkretne bitwy i ról, jakie w nich odgrywali. Na zakończenie warto przyjrzeć się powojennym losom osób walczących na frontach hiszpańskiej wojny domowej, jeśli tylko da się to ustalić.

Wstępne zarysowanie zagadnień badawczych tego tomu nie wydawało się trudne, ale w miarę przeprowadzanych analiz okazywało się, że wiedza zgromadzona do tej pory przez historyków jest dosyć powierzchowna, częstokroć ogólnikowa, nieraz wzajemnie do siebie nieprzystająca lub nawet sprzeczna i niepozwalająca na ustalenie najistotniejszych kwestii. Sięgnięcie do źródeł okazywało się jednakże odsłonięciem przysłowiowego wierzchołka góry lodowej. Jest ich zdecydowanie więcej, niż można się było spodziewać. Wynikające z nich informacje trzeba było uogólniać, aby zmieścić się w ramach planowanego tomu. Wyczerpanie tematu okazuje się możliwe dopiero po kolejnych solidnych kwerendach materiałów archiwalnych, prasowych, memuarystyki czy innych dostępnych źródeł. Przedkładany tom ma więc raczej charakter wstępnego i dość syntetycznego ustalenia pól badawczych, co otwierałoby na przyszłość kolejne możliwości prowadzenia badań. Mimo wstępnego charakteru ustaleń, przygotowanie tego tomu wydaje się jednakże ze wszech miar uzasadnione, choćby w celu przedstawienia zainteresowanym stanu zaawansowania dotychczasowych prac naukowych.

Schemat prezentowanych tekstów jest podobny. Zawiera elementy pozwalające odpowiedzieć na zawarte powyżej pytania badawcze. Na pewno prezentowany tom daleki jest od kompletności nie tylko od strony wykorzystanych materiałów źródłowych, lecz także uwzględnionych narodowości. O doborze decydowała liczebność obcokrajowców z danego państwa w walkach na frontach hiszpańskiej wojny domowej. Nie uwzględniono więc reprezentacji mniejszych narodów, które również odegrały niemałą rolę w zmaganiach zbrojnych, jak choćby Węgrów na stanowiskach dowódczych po stronie Frontu Ludowego, Słowian różnych narodowości czy Rumunów spod znaku Żelaznej Gwardii w szeregach zwolenników generała Franco. Cały tom rozpoczyna rozdział o najliczniejszych po stronie rządu Frontu Ludowego Francuzach autorstwa FrédéricA DessberGa. Po nim następuje tekst MARIUSZA WoŁosA o najbardziej znaczących w działaniach militarnych, choć nie tak licznych, przedstawicielach Związku Sowieckiego, którzy w dość wczesnej fazie wojny domowej przejęli kierownictwo nad operacjami broniącej się przed rebelią strony. Trzeci artykuł, autorstwa JACKA PIETRZAKA, dotyczy udziału Polaków w walkach w dalekim od ojczyzny kraju. W następnej kolejności HANNA MARCZEWSKA-ZaGDAŃSKA pisze o Amerykanach w Hiszpanii, koncentrując się 
na udziale ochotników tej nacji w Brygadach Międzynarodowych. Podobny w swym charakterze jest tekst DARIUSZA JEZIORNEGo. Wspomina on o zwolennikach generała Franco, którzy przybyli bić się w jego sprawie zza Kanału La Manche, tym niemniej zdecydowanie bardziej wyczerpująco ujmuje zaangażowanie Brytyjczyków w przeciwnym mu obozie. PIOTR BeDnarz podejmuje prawie zupełnie nieznany polskiemu czytelnikowi problem udziału ok. 800 Szwajcarów w wojnie domowej w Hiszpanii. Zaraz po nim Katarzyna JedynaKiEwICZ-Mróz charakteryzuje licznie stawiających się do boju Niemców, którzy przelewali krew po obu stronach frontu. Zarówno Legion Condor, jak i ochotnicy pochodzący z szeregów antynazistowskiej emigracji odegrali na frontach hiszpańskich poważne role. Niewiele mniej istotny był udział Portugalczyków, którzy też funkcjonowali jako ochotnicy w Hiszpanii, lecz w przeważającej części opowiadali się przeciwko rządom hiszpańskiej lewicy. BARTOSZ KACZOROWSKI w swoim tekście skoncentrował się właśnie na nich. Dziewiąty artykuł, autorstwa XaVIERA Moreno JuliI, traktuje o bardzo licznym udziale Włochów w hiszpańskiej wojnie domowej, najliczniejszej grupie obcokrajowców walczących w obu obozach, choć autor skupił się przede wszystkim na zaangażowaniu oddziałów przysłanych przez Benito Mussoliniego. Drugi tekst Bartosza KaCzorowskiego opisuje rolę Marokańczyków w działaniach wojennych w Hiszpanii. Znalazł się on w tomie, ponieważ udział tej grupy był bardzo liczny i w pierwszych miesiącach wojny to głównie dzięki nim generał Franco „miał kim walczyć”. Nie było wprawdzie jasne, czy można traktować Marokańczyków jako cudzoziemców - zamieszkiwali wszak na terytorium zależnym od Madrytu - ale na pewno trudno byłoby ich uznać za Hiszpanów. Biorąc zaś pod uwagę wielką rolę, jaką odegrali w szeregach zwolenników frankistów, warto się z nimi zapoznać. Tekst pokazuje zresztą, jak bardzo złożone były czynniki prowadzące do rekrutowania bojowników po obu stronach walczących. Przykład muzułmańskich „Maurów”, którzy opowiedzieli się za katolickimi konserwatystami i „nacjonalistami hiszpańskimi”, dawał ku temu znakomity pretekst.

\section{$* * *$}

Podsumowując wyniki dotychczasowych badań nad udziałem obcokrajowców w wojnie domowej w Hiszpanii, należy stwierdzić, że odegrali oni rolę trudną do przecenienia. Nawet biorąc pod uwagę najskromniejsze szacunki historyków, trudno oprzeć się wrażeniu, że to właśnie cudzoziemcy bili się w hiszpańskich zmaganiach. Rzecz jasna nie wszyscy ci ludzie znaleźli się na Półwyspie Iberyjskim w jednym momencie. Tym niemniej jednak liczby mówią same za siebie. Po stronie zwycięskich $\mathrm{w}$ ostatecznym rozrachunku rebeliantów walczyło powyżej 181 tys. żołnierzy z innych krajów, a po stronie rządu Frontu Ludowego ok. 43 tys. osób. Szczególnie w pierwszej fazie zmagań, gdy oba walczące obozy nie zbudowały jeszcze masowych armii sięgających do $0,5 \mathrm{mln}$ ludzi, udział 
obcokrajowców właśnie miał podstawowe znaczenie. Jego spadek widać szczególnie dotkliwie w Brygadach Międzynarodowych. W ich szeregach po bitwie pod Brunete w lipcu 1937 r. liczba nowych rekrutów wyraźnie spadła i nie dało się jej już uzupełnić kolejnymi falami ochotników zagranicznych. Inaczej sytuacja przedstawiała się po stronie generała Franco - tam udział „ochotników” zależał w dużej mierze od rządów Włoch, Portugalii i Niemiec. A one, czerpiąc ze zwycięstwa buntowników różnorakie korzyści, wysyłały swoje oddziały i sprzęt wojskowy do Hiszpanii. Dzięki temu wojna domowa mogła się w ogóle skończyć. To, że włoskie bombardowania miast wiernych rządowi Frontu Ludowego przesądziły w dużej mierze wyniki kolejnych ofensyw frankistów w 1938 i w początkach 1939 r., jest oczywiste.

Motywy przyjazdu do Hiszpanii osób chętnych do walki nie są łatwe do ustalenia. Istniejąca literatura pamiętnikarska oraz dokumenty z archiwów państwowych i prywatnych dają ku temu duże możliwości. Z przebadanych do tej pory źródeł widać, że pewne treści się jednakże pokrywają. Pomijając tych kombatantów, którzy musieli wyjechać do Hiszpanii na podstawie decyzji swoich rządów, u bojowników obu stron wyraźne są względy ideologiczne. Po stronie rządu Frontu Ludowego walczyli zwykle ludzie, głoszący niechęć do faszyzmu. Natomiast do walki z lewicowym rządem zgłaszali się niejednokrotnie antykomuniści. Oprócz motywu ideologicznego pojawiały się również pomysły przeżycia romantycznej przygody na wojnie, o której można by później opowiadać znajomym, ukochanej dziewczynie lub dzieciom. Nierzadko taka właśnie chęć popisu była związana z decyzją o wyjeździe, choć romantycznej wizji wojny towarzyszyły też niejednokrotnie dążenia do bycia częścią większej społeczności, występującej w jakiejś słusznej sprawie. Idea jedności międzynarodowej, braterstwa i poświęcenia aż do utraty życia to nierzadkie motywy wyborów młodych mężczyzn. Do tych powodów, które można by nazwać dążeniem do przeżycia największej przygody życia, dochodziły nadzieje na poznanie pięknych hiszpańskich dziewczyn. Wszystko to podszyte było wielokroć dużą dozą awanturnictwa. Innym argumentem za wyjazdem do Hiszpanii były względy finansowe. Podpisywane kontrakty, czy to przez zawodowych żołnierzy niemieckich lub włoskich, czy też przez ochotników jadących na wojnę z faszyzmem, zawierały w treści również ten aspekt. Jeśli więc ktoś był emigrantem politycznym lub bezrobotnym w swoim kraju, aspekty finansowe decyzji nie były bez znaczenia. Podobnie było z zawodowcami walczącymi po stronie generała Franco, przy czym ich kontrakty były przynajmniej przestrzegane. Wśród walczących ochotników byli wreszcie i tacy, którzy nie byli zbytnio świadomi, w co tak naprawdę postanowili się zaangażować. Zeznania tego typu trudno niestety traktować poważnie. Co prawda wyrobienie polityczne ochotników pozostawiało wiele do życzenia, lecz każdy wiedział, że w Hiszpanii toczyła się wojna. Stąd chęć rezygnacji ze służby po pierwszych traumatycznych doświadczeniach wojennych na podstawie argumentu o wprowadzeniu w błąd przez osoby rekrutujące do rzekomo innej pracy nie przekonują. Nie przekonywały zresztą również 
dowódców, którzy pod żadnym pozorem nie zamierzali pozbywać się żołnierzy, tak bardzo potrzebnych w pierwszej fazie wojny, gdy ci zamierzali się wycofać $\mathrm{z}$ walk. Jedyną w tej sytuacji koncepcją na wycofanie się z szeregów walczących były dezercje, nierzadkie szczególnie po stronie Frontu Ludowego. Jednakże czy podobne ucieczki nie zdarzały się po drugiej stronie? Warto to zbadać.

Walczący w Hiszpanii cudzoziemcy dostawali się na teren objęty bratobójczymi walkami na różne sposoby. W przypadku zwolenników rządu największe znaczenie odgrywała Francja, jako kraj tranzytowy. W pierwszych miesiącach wojny, gdy granica w Pirenejach była praktycznie otwarta dla przechodzących na stronę hiszpańską, przez Perpignan oraz Marsylię dostawały się tysiące ochotników. Od lutego $1937 \mathrm{r}$. było to teoretycznie zakazane, lecz lokalne władze i tak przymykały oczy na przekraczających góry ochotników, którzy dzięki temu właśnie uzyskiwali miano ludzi idących do walki z największym poświęceniem, bez zwracania uwagi na poważne utrudnienia. $Z$ kolei walczący po stronie rebeliantów dostawali się do Hiszpanii bądź na statkach, bądź też samolotami. W uprzywilejowanej sytuacji byli w tym wypadku Portugalczycy, ponieważ władze w Lizbonie całkowicie wspierały wojska generała Franco na różne sposoby. A że bezpośrednia granica nie stanowiła żadnej przeszkody do sforsowania, to jej przekraczanie było bezproblemowe.

Tworzone przez obcokrajowców jednostki wojskowe tylko w dwóch przypadkach miały charakter narzucony przez ich własne rządy. Niemcy i Włosi mieli w kwestiach organizacyjnych całkowitą samodzielność i generał Franco nie miał większego wpływu na ich kroki. W pozostałych przypadkach zwolenników generała Franco wcielano do Armii Narodowej. Gdy chodzi o walczących po stronie rządu Frontu Ludowego, to przybywający nie mieli nic do powiedzenia w kwestii, jak będą zorganizowani w walce. Starano się ich pogrupować tak, aby walcząc ramię w ramię, potrafili zrozumieć siebie nawzajem i rozkazy wydawane przez dowódców. Trzeba jednakże zauważyć, że nie wszyscy ochotnicy kwalifikowali się do walki w Brygadach Międzynarodowych ze względu na różnice polityczne. Były one szczególnie wyraźne między komunistami, sprawującymi całkowitą kontrolę nad Brygadami, a anarchistami i innymi rewolucyjnie nastawionymi grupami, jak POUM. Dalsze badania nad zagadnieniem organizacji, wpływu na posyłanie poszczególnych oddziałów do boju, sposobu komunikowania się dowódców z władzami centralnymi po obu stronach frontu wymagają jednakże dalszych badań. W przypadku Włochów, Niemców i Portugalczyków warto je przeprowadzić w archiwach wojskowych państw wysyłających. Natomiast walczący po stronie rządu Frontu Ludowego w zdecydowanej większości zależni byli od decyzji Kominternu i to w zbiorach pozostawionych przez tę organizację należałoby podjąć kwerendę. Co do ochotników niemających prokomunistycznych tendencji, do przebadania pozostają archiwa partyjne ugrupowań wysyłających swoich zwolenników do Hiszpanii. 
Od początku wojny obcokrajowcy uczestniczyli we wszystkich najważniejszych bitwach: opanowaniu kolonii hiszpańskich, walkach w Andaluzji i Estremadurze, bitwie o Madryt we wszystkich jej odsłonach aż po ofensywę rządową pod Brunete, zmaganiach w Baskonii i Aragonii ze szczególnym uwzględnieniem przełomowych starć o Teruel, ostatniej ofensywie sił antyrebelianckich nad rzeką Ebro, wreszcie zdobywaniu ostatnich enklaw oporu sił prorządowych w Katalonii i Walencji. O ile ochotnicy walczący po stronie prezydenta Azañi i premiera Negrina wycofani zostali z frontu we wrześniu 1938 r., o tyle udział Włochów i Niemców w znaczącym stopniu przysłużył się zakończeniu wojny na korzyść rebeliantów. Ten element udziału cudzoziemców w wojnie wydaje się najsolidniej przebadany i opisany w literaturze przedmiotu. Pogłębienia wymagać może co najwyżej zagadnienie wpływu doradców sowieckich na podejmowane inicjatywy militarne w obozie prorządowym.

Rozmiar strat wśród cudzoziemców wciąż jest trudny do ustalenia, nikt bowiem nie kwapił się z ogłaszaniem takich informacji. W celu określenia liczby zabitych potrzebne są niewątpliwie dalsze solidne badania. Tutaj historycy mieliby szczególnie wiele do zrobienia. $Z$ tego, co do tej pory zdołano ustalić, wynika, że wojna była bardzo krwawa. Z szeregowymi rekrutami nikt z dowódców specjalnie się nie liczył. Szacunkowe dane odnoszące się do strat Marokańczyków zostały w niniejszym tomie określone na $12 \%$ zabitych. W obozie popierającym generała Franco były to straty najwyższe. W szeregach Włochów były one zdecydowanie niższe, a wśród Niemców najniższe. Z kolei w obozie przeciwnym szacunki są jeszcze bardziej przybliżone. Trzeba jednakże pamiętać o zakwalifikowaniu Brygad Międzynarodowych do oddziałów szturmowych, stąd podejmowane przez nie akcje z definicji generowały duże straty. Powracający do kraju Brytyjczycy stanowili mniej niż połowę wyjeżdżających do Hiszpanii ochotników. Losy powojenne Włochów i Niemców, walczących „przeciw faszystom”, są w dużej mierze mgliste i rozmiar ich strat trudno jest określić - nie wracali bowiem do domów, ponieważ tam drzwi były zamknięte z powodów politycznych.

Po wojnie, jak widać z całości monografii, życie żołnierzy, którzy przetrwali wojnę i wrócili do ojczyzny, było zróżnicowane. Walczący po zwycięskiej stronie Niemcy czy Włosi zdobyli cenne doświadczenia, które później wykorzystywali na frontach II wojny światowej. Dla nich powrót do domów z nimbem bohaterów był awansem. Inaczej było w przypadku przeżycia przez nich II wojny światowej, po której nazistowscy i faszystowscy ,bohaterowie” nie byli już bohaterami. Odmiennie było w Portugalii, gdzie powracających kombatantów starano się ukryć, aby nie zadrażniać relacji z Wielką Brytanią. Niewątpliwie mogli oni być rozczarowani przymusowym zapomnieniem. Powracający do krajów Brytyjczycy i Amerykanie częściowo kontynuowali swoją działalność polityczną, ale większość się z niej wycofała. Francuzi z Brygad Międzynarodowych zasilili w większości Résistance, czyli kontynuowali zmagania z „faszyzmem”. Niewątpliwie 
doświadczenia z czasów wojny domowej w Hiszpanii były im przydatne. Na terenie Francji stacjonowali także polityczni emigranci z Włoch i Niemiec, a także Polacy, którzy na wojnę pojechali już jako emigranci ekonomiczni z Rzeczypospolitej. Z kolei po II wojnie światowej wracali do wschodnich Niemiec, Polski i innych krajów podporządkowanych Związkowi Sowieckiemu jako członkowie nowych elit politycznych i wojskowych. W większości nie osiągnęli jednakże najważniejszych stanowisk państwowych.

Na wszystkich zarysowanych polach badawczych jest jeszcze wiele do zrobienia. Tematyka wydaje się bardzo zachęcająca do dalszych kwerend, mimo możliwych zniszczeń dokumentów w trakcie II wojny światowej. Do przebadania, oprócz dokumentów personalnych i gromadzonych przez policje krajów pochodzenia ochotników, pozostaje cała gama źródeł prasowych i wspomnieniowych, znajdujących do tej pory niewielkie zainteresowanie historyków. Niewątpliwie bardzo wiele do powiedzenia będą miały dokumenty Międzynarodówki Komunistycznej, po które trzeba by się wybrać do Moskwy. Mimo rozproszenia źródeł perspektywy dalszej, pogłębionej pracy wydają się bardzo interesujące.

DARIUSZ JEZIORNY 